
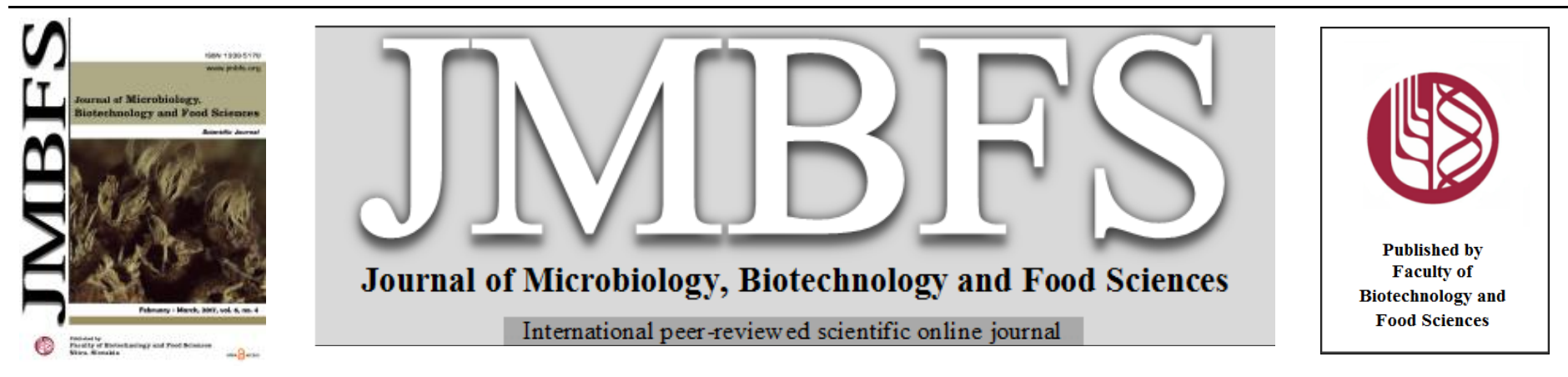

\title{
AMINO ACIDS PRODUCTION BY PROTEOLYTIC MUCOR MUCEDO STRAIN SEE1 ON THE OPTIMIZED FERMENTATION MEDIUM
}

\author{
Mohammed S. El-Hersh ${ }^{1}$,Noura El-Ahmady El-Naggar ${ }^{2}$, WesamEldin I.A. Saber ${ }^{1}$, and Mohammed K. Mahmoud ${ }^{1}$
}

\author{
Address(es): \\ ${ }^{1}$ Microbial Activity Unit, Department of Microbiology, Soils, Water and Environment Research Institute, Agricultural Research Center (ID: 60019332), Giza (P.N. \\ 12619), Egypt. \\ ${ }^{2}$ Department of Bioprocess Development, Genetic Engineering and Biotechnology Research Institute, City of Scientific Research and Technological Applications, \\ Alexandria, New Borg El-Arab City, Egypt.
}

*Corresponding author: nouraelahmady@yahoo.com

doi: 10.15414/jmbfs.2017.6.4.1036-1042

\section{ARTICLE INFO}

Received 19. 4. 2016

Revised 5. 9. 2016

Accepted 1. 12. 2016

Published 1. 2. 2017

Regular article

OPEN $\partial_{\text {ACCESS }}$

\begin{abstract}
The present study has been conducted to isolate the potential fungal isolates in proteolysis process. One isolate showed high activity in protease production, being Mucor sp. Morphological and microscopical studies, as well as 18S rRNA sequence confirmed that this isolate is identified as Mucor mucedo strain SEE1 and sequencing product was deposited in the GenBank database under the accession number KP736529. Optimization of protease production during Plackett-Burman and central composite designs has been carried out, with six nutritional variables. Glucose and casein were significantly superior to other variables in protease production. Moreover, an overall 3.36-fold increase in protease production has been obtained by Placket-Burman. However, 1.14-fold increase was found in central composite design. On the other hand, during the fermentation process in optimized medium, liberated amino acids has been determined $(\mu \mathrm{g} / \mathrm{ml})$, where histidine came in the first order (1155.3) followed by lysine (897.4), tyrosine (634), arginine (580) and isoleucine (580), respectively. However, cysteine was found in less appreciable amount (36).
\end{abstract}

Keywords: Amino acids production; Mucor mucedo strain SEE1; protease; statistical optimization; 18S rRNA

\section{INTRODUCTION}

Proteolysis process occurred through the chemical or enzymatic hydrolysis of proteinaceous compounds, several microbial enzymes are involved in this process. In this respect, protease enzymes are one of the most important microbial enzymes, which widely used in many industries, e.g. food, pharmaceutical, detergent, leather and silk (Gessesse, 1997, Kembhavi et al., 1993, Ivanov et al., 2013). This group represents one of the largest groups of industrial enzymes and accounts for approximately $60 \%$ of the total enzyme sales in the world (Zambare $\boldsymbol{e t}$ al., 2011). Moreover, microbial proteases are gaining more importance than conventional chemicals that cleave protein, produce peptides and amino acids because of the cheaper production cost and use of renewable resources (Souza et al., 2015). These enzymes can be produced from bacteria, fungi and yeasts using many processes like submerged fermentation culture (Haki and Rakshit, 2003). Currently, a large proportion of commercially available proteases is derived from fungi such as Aspergillus flavus (Kranthi et al., 2012). Aspergillus oryzae (Vishwanathaet al., 2010a), Penicillium griseoroseum (Ikram-Ui-Haq and Mukhtar, 2007), Rhizopus oryzae (Kumar et al., 2005), Mucor circinelloides (Andrade et al., 2002) and Thermomucor indicaeseudaticae (Merheb-Dini et al., 2010). Although, fungal proteases have attracted the attention of environmental biotechnologists because fungi can grow on low-cost substrates and secrete large amount of enzymes intotheculture medium, which could ease downstream processing (Anitha and Palanivelu, 2013). As well as, the production cost acting 30-40\% of the growth medium and this is interest from an industrial point of view (Joo et al., 2003). Generally, protease production is greatly influenced by media component and physical factors (Potumarthi et al., 2007). Wherein, the industrial fermentation is moving away from traditional and largely empirical operation towards knowledge based and better-controlled process (Singh et al., 2004). Therefore, a number of optimization techniques could be used for this purpose, by which the statistical approaches offer ideal ways for optimization process in biotechnology (Gupta $\boldsymbol{e t}$ al., 2002). Response surface methodology one of these approaches, which includes center composite design, helps in evaluating the effective factors and in building models to study interaction and select optimum conditions of variables for a desirable response (Dutta et al., 2004). Proteolysis process generally associated with some amino acids and nitrogenous compounds (Ventura et al.,
2012). Amino acids have been taken as an important tool for nutritional status, especially in patients suffering from inborn errors of metabolism (IEM) and for monitoring therapy in patients with IEM, as well. Additionally, amino acids are recommended as food supplements for body building, sleep aid, depression therapy, premenstrual dysphoric disorder, smoking cessation, bruxism (Ivanov et al., 2013). Wherein, using the new biotechnology for such production of these amino acids considered a new trend to face the shortage in human nutrition, especially in developed countries. Herein, our study aimed to (i) study the efficacy of the new isolate of Mucor sp. in proteolysis and optimization of protease enzyme, (ii) determination of amino acids associated with the proteolysis process.

\section{MATERIAL AND METHODS}

Mucor sp. was isolated on skim agar plates. The fungus showed high proteolytic activity among all the isolated ones, so it was selected for the next trials. The selected fungus was identified upon the morphological and microscopic investigations, according to Domsch et al. (1980), in addition to molecular identification.

\section{Molecular identification of the isolated Mucor sp.}

A $18 \mathrm{~S}$ rRNA sequencing was performed by Macrogen Korea Company Gasandong, Geumchen-gu, Seoul, Korea (http://www.macrogen.com). The genomic DNA was isolated by transferring fungal mycelium with a sterilized toothpick, suspended in $0.5 \mathrm{ml}$ of sterilizes saline in a $1.5 \mathrm{ml}$ centrifuge tube and centrifuged at $10000 \mathrm{rpm}$ for $10 \mathrm{~min}$. Then the supernatant was discarded and the pellet was resuspended in $0.5 \mathrm{ml}$ of InstaGene Matrix (Bio-Rad, USA). Incubated at $56{ }^{\circ} \mathrm{C}$ for $30 \mathrm{~min}$ and then heated at $100{ }^{\circ} \mathrm{C}$ for $10 \mathrm{~min}$. After heating, the supernatant can be used for PCR. The PCR amplification reaction was performed in a total volume of $100 \mu \mathrm{l}$, which contained $1 \mu \mathrm{l}$ DNA, $10 \mu \mathrm{l}$ of $250 \mathrm{mM}$ deoxyribonucleotide 5'-triphosphate (dNTP's); $10 \mu \mathrm{l}$ PCR buffer, $3.5 \mu \mathrm{l} 25 \mathrm{mM}$ $\mathrm{MgCl}_{2}$ and $0.5 \mu \mathrm{l}$ Taq polymerase, $4 \mu \mathrm{l}$ of $10 \mathrm{pmol}$ (each) forward primer ITS1 (3'-TCCGTAGGTGAACCTGCGG-5') and reverse primer ITS4 (5'TCCTCCGCTTATTGATATGC-3') and water was added up to $100 \mu \mathrm{l}$. The PCR-apparatus was programmed as follows: $5 \mathrm{~min}$ denaturation at $94{ }^{\circ} \mathrm{C}$, 
followed by 35 amplification cycles of $1 \mathrm{~min}$ at $94{ }^{\circ} \mathrm{C}, 1 \mathrm{~min}$ of annealing at $55^{\circ} \mathrm{C}$, and $2 \mathrm{~min}$ of extension at $72{ }^{\circ} \mathrm{C}$, followed by a $10 \mathrm{~min}$ final extension at 72 ${ }^{\circ} \mathrm{C}$. Unincorporated PCR primers and dNTPs were removed from PCR products by using Montage PCR Cleanup kit (Millipore). The PCR reaction mixture was then analyzed via 1\% (w/v) agarose gel electrophoresis (Figure1), and the remaining mixture was purified using QIA quick PCR purification reagents (Qiagen, USA)

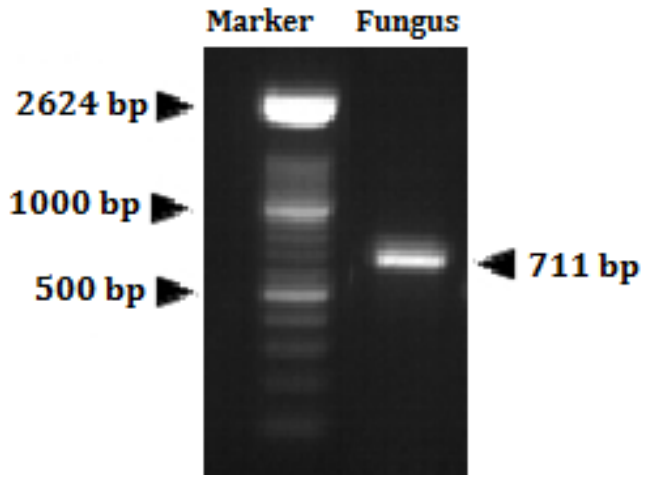

Figure1 Agarose gel electrophoresis of the amplified ITS fragment of the Mucor mucedo strain SEE1.

The purified PCR products were sequenced. Sequencing reactions were performed in a MJ Research PTC-225 Peltier Thermal Cycler using an ABI PRISM $®$ BigDyeTM Terminator Cycle Sequencing Kits with AmpliTaq-DNA polymerase (FS enzyme) (Applied Biosystems), following the protocols supplied by the manufacturer. Single-pass sequencing was performed on each template using the last mentioned PCR-primers. The fluorescent-labeled fragments were purified from the unincorporated terminators with an ethanol precipitation protocol. The samples were resuspended in distilled water and sequencing products were resolved on an Applied Biosystems model 3730XL automated DNA sequencing system (Applied BioSystems, USA). The sequencing product was deposited in the GenBank database under accession numbers KP736529.The $18 \mathrm{~S}$ rRNA gene sequence (667bp) of the strain was aligned with the corresponding $18 \mathrm{~S}$ rRNA sequences of the type strains of representative members of the fungi retrieved from the GenBank, EMBL, DDBJ and PDB databases by using BLAST program (http://www.ncbi.nlm.nih.gov/BLAST) (Altschul et al. 1997) and the software package MEGA4 version 2.1 (Tamura et al., 2007) was used for multiple alignment and phylogenetic analysis. The phylogenetic tree was constructed via the neighbor-joining algorithm (Saitou and Nei, 1987) based on the 18S rRNA gene sequences of the strain and related organisms.

\section{Submerged liquid state fermentation (LSF) and time course profile}

Plates of Sabouraud agar were inoculated and incubated at $35^{\circ} \mathrm{C}$ for $72 \mathrm{~h}$, the inoculum was obtained by scraping the agar surface in the presence of sterile water, to obtain $10^{6}$ spore $\mathrm{ml}^{-1}$, by Neubauer Chamber. The composition of the protease production medium contained $\left(\mathrm{g} \mathrm{l}^{-1}\right)$, glucose (18), peptone (8), casein (4), $\mathrm{KH}_{2} \mathrm{PO}_{4}$ (2), olive cake (4) and corn steep liquor (CSL) (4). The initial pH was adjusted to 5.0 and sterilized at $121^{\circ} \mathrm{C}$ for 15 minutes. $10 \%(\mathrm{v} / \mathrm{v})$ of inoculum was transferred to 250-ml Erlenmeyer flasks containing $45 \mathrm{ml}$ of sterilized liquid fermentation medium. Incubation was carried out at $35{ }^{\circ} \mathrm{C}$ under shaking at $150 \mathrm{rpm}$. The optimum incubation period was determined on this medium along for 5 days.

\section{Protease activity assay}

Protease activity was quantitatively assayed in a mixture consisted of $1 \mathrm{ml}$ crude protease and $1 \mathrm{ml}$ of $2 \%$ casein in $0.1 \mathrm{M}$ tris-HCL buffer, $\mathrm{pH} 7.5$, then incubated at $37^{\circ} \mathrm{C}$ for $20 \mathrm{~min}$ (Abou-Ayana et al., 2015). One unit (U) of protease activity was defined as the amount of the enzyme resulting in the release of $0.5 \mu \mathrm{g}$ of tyrosine equivalent $\mathrm{ml}^{-1} \mathrm{~min}^{-1}$ under the assay conditions.

\section{The fractional factorial Plackett-Burman design}

Six components of LSF medium were screened at high $(+1)$ and low $(-1)$ levels in addition to three center point (0), using Plackett-Burman design. The relation between the coded and actual values was calculated by the following equation: $\mathrm{x}_{\mathrm{i}}=\left(\mathrm{X}_{\mathrm{i}}-\mathrm{X}_{0}\right) / \Delta \mathrm{X}_{\mathrm{i}}$

Where; $X_{i}$ is the coded value of an independent variable, $X i$ is the real value of an independent variable, $\mathrm{X}_{0}$ is the real value of an independent variable at the center point, and $\Delta \mathrm{X}_{\mathrm{i}}$ is the step change value. The main effect of each variable was calculated using the following equation:

$\operatorname{Effect}\left(\mathrm{x}_{\mathrm{i}}\right)=2\left(\sum \mathrm{M}_{\mathrm{i}}^{+1}-\mathrm{M}_{\mathrm{i}}^{-1}\right) / \mathrm{N}$
Where; $\mathrm{X}_{\mathrm{i}}$ is the effect of the tested variable. $\mathrm{M}_{\mathrm{i}}^{+1}$ and $\mathrm{M}_{\mathrm{i}}^{-1}$ represent fungal protease production from the trials where the variable $\left(\mathrm{X}_{\mathrm{i}}\right)$ measured was present at high and low concentration, respectively, $\mathrm{N}$, the total number of trials.

\section{Central composite design}

Fermentation factors affecting fungal protease production were optimized using the full central composite design (CCD). The significant variables (Glucose, $\mathrm{X}$ and casein, $X_{3}$ ) from screening experiment were further investigated for studying the interaction between the two variables. The other medium components were kept at their minimal concentrations. Each of the two factors was examined at five different levels; at the center point and an axial point located at a specified distance (alpha, $\alpha=1.414$ ) from the design center in each direction on each axis. According to the applied design, 13 combinations were executed. The observations of the two factors were fitted to the following second order polynomial quadratic model:

$\mathrm{Y}=\beta_{0}+\sum \beta_{\mathrm{i}} \mathrm{X}_{\mathrm{i}}+\sum \beta_{\mathrm{ij}} \mathrm{X}_{\mathrm{i}} \mathrm{X}_{\mathrm{j}}+\beta_{\mathrm{ii}} \mathrm{X}_{\mathrm{i}}^{2}$

Where; $Y$ is the predicted response, $\beta_{0}$ model constant, $X_{i}$, and $X_{j}$ independent variables; $\beta_{\mathrm{i}}$, is linear coefficients; $\beta_{\mathrm{i} i}$, is cross product coefficients and $\beta_{\mathrm{ii}}$ is the quadratic coefficients.

\section{Statistical analysis}

The statistical analysis of Plackett-Burman and CCD results was performed with the aid of statistical analysis software Minitab ver. 10. The statistical analysis software package, Statistica ver. 8.0, was used to create the three-dimensional surface plot.

\section{Amino acids determination}

Free amino acids were quantified from culture supernatants. The culture samples were filtered and hydrolyzed with $6 \mathrm{M} \mathrm{HCL}$ for $24 \mathrm{~h}$ at $110^{\circ} \mathrm{C}$ under a vacuum, and amino acid contents were measured using Sykam57130amino acid reagent organizer (Lee et al., 2014).

\section{RESULTS AND DISCUSSION}

Fungal isolates were selected according to their proteolysis activity on skim milk agar, the potent isolate was selected and morphologically investigated. This isolate is belonging to Mucor sp. These findings are in accordance with previous studies that showed a great number of fungal strains have potential proteolysis, e.g. Aspergillus niger (O'Donnell et al., 2001), A. flavus (Kranthi et al., 2012), Mucor pusillus, M. miehei and M. circinelloides (Andrade et al., 2002).

\section{Molecular identification}

The nucleotide sequence of Mucor mucedo strain SEE1 has been compared with other fungal species sequences using BLAST algorithm at the website http://blast.ncbi.nlm.nih.gov/Blast.cgi, and the sequence was assembled and deposited in the NCBI Genbank with accession number KP736529. The phylogenetic analysis of Mucor mucedo strain SEE1revealed 100\% similarity with Mucor mucedo strain CBS 987.68 (accession number JN939204.1). A phylogenetic tree (Figure2) was constructed according to the neighbor-joining method of Saitou and Nei (1987) with MEGA4 (Tamura et al., 2007). The topology of the phylogenetic tree was evaluated by using the bootstrap resembling method of Felsenstein (1985) with 1000 replicates. This tree showed a close phylogenetic association of Mucor mucedo strain SEE1 with $M$. mucedo species. Phylogenetic analysis indicated that the strain SEE1 falls into a clade together with $M$. mucedo strain CBS 640.67 (accession number HM849687.1, $99 \%$ similarity to $M$. mucedo strain SEE1 ), M. piriformis strain CBS 169.25 (accession number HM849681.1, 95\% similarity to Mucor mucedo strain SEE1), $M$. luteus strain CBS 243.35 (accession number HM849685.1, 93\% similarity to $M$. mucedo strain SEE1), Rhizomucor variabilis strain CBS 103.93 (accession number HM849684.1, 93\% similarity to $M$. mucedo strain SEE1).Therefore, it is proposed that strain SEE1should be included in the genus Mucor as M. mucedo strain SEE1. 


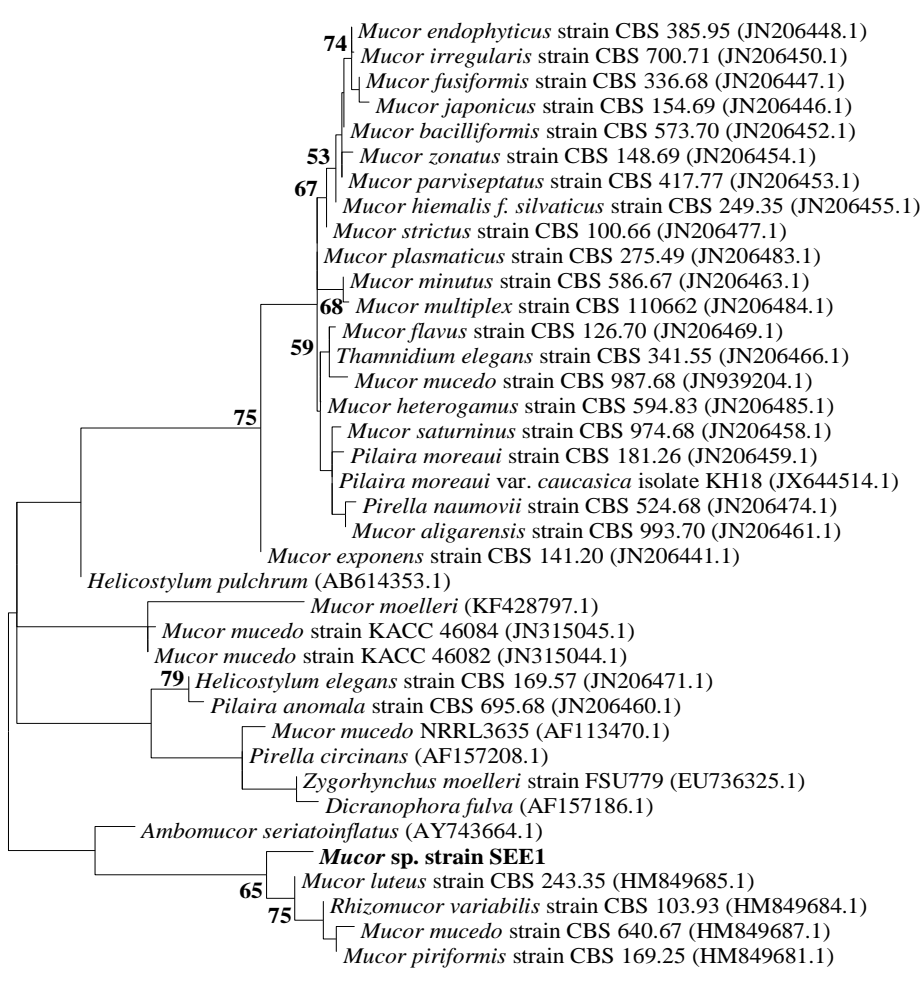

$\stackrel{\longmapsto}{0.5}$

Figure 2 The phylogenetic tree of M. mucedo strain SEE1 with respect to the closely related sequences available at the GenBank.

\section{Time course for protease production}

Time course of protease production by $M$. mucedo strain SEE1 was monitored for 5.0 days at $24 \mathrm{hr}$ intervals. As shown in Figure3, the maximum protease production was recorded after the second day of fermentation $(3.859 \mathrm{U} / \mathrm{ml} / \mathrm{min})$ Then, protease production is decreased with further time of incubation.

\section{Screening of medium components by Plackett-Burman design}

The influence of six variables, namely; glucose, peptone, casein, $\mathrm{KH}_{2} \mathrm{PO}_{4}$, olive cake and $\quad \mathrm{CSL}$, on the protease production by $M$. mucedo strain SEE1 was investigated using Plackett-Burman design with three center points. Among the screened medium component, several nitrogen sources were evaluated to select the suitable one for amino acids biosynthesis, of them CSL as an economic source of nitrogen may also act as a carbon source at the same time, however, olive cake may be served as another source of carbon.The design and the corresponding response of protease production are shown in Table (1).

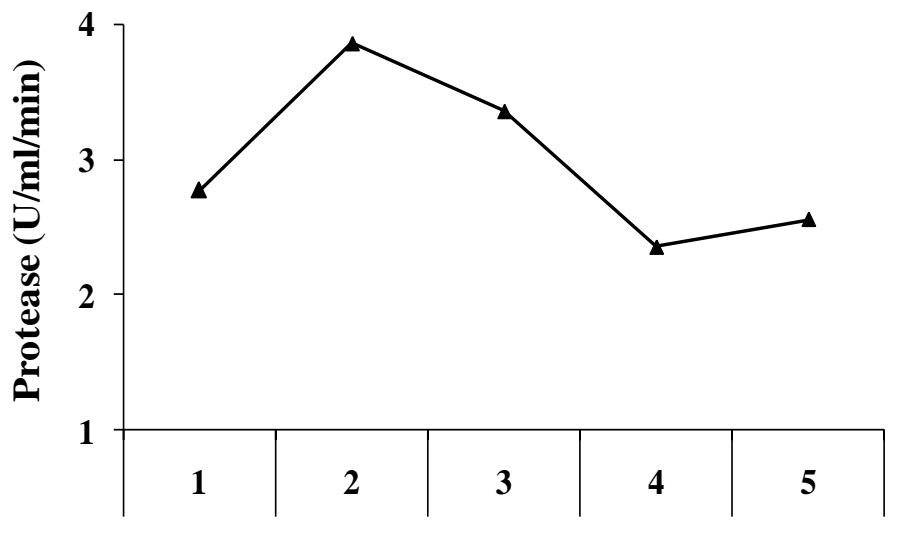

Time (day)

Figure3 Profile of protease production by $M$. mucedo strain SEE1 along 5 days incubation

Table 1 Actual and coded values of medium components based on Plackett-Burman design and corresponding experimental and fitted protease activity by $M$. mucedo strain SEE1.

\begin{tabular}{|c|c|c|c|c|c|c|c|c|c|}
\hline \multirow{3}{*}{ Run } & \multicolumn{6}{|c|}{ Medium component (g/l) } & & & \multirow{3}{*}{ Residua } \\
\hline & \multirow{2}{*}{$\begin{array}{l}\text { Glucose } \\
\left(\mathbf{X}_{1}\right)\end{array}$} & \multirow{2}{*}{$\begin{array}{l}\text { Peptone } \\
\left(\mathbf{X}_{2}\right)\end{array}$} & \multirow{2}{*}{$\begin{array}{l}\text { Casein } \\
\left(\mathbf{X}_{3}\right)\end{array}$} & \multirow{2}{*}{$\begin{array}{l}\mathrm{KH}_{2} \mathrm{PO}_{4} \\
\left(\mathrm{X}_{4}\right)\end{array}$} & \multirow{2}{*}{$\begin{array}{l}\text { Olive cake } \\
\left(\mathbf{X}_{5}\right)\end{array}$} & \multirow{2}{*}{$\begin{array}{l}\text { CSL } \\
\left(\mathbf{X}_{6}\right)\end{array}$} & \multicolumn{2}{|c|}{ Protease (U/ml/min) } & \\
\hline & & & & & & & Experimental & Fitted & \\
\hline 1 & $25(1)$ & $4(-1)$ & $6(1)$ & $1(-1)$ & $2(-1)$ & $2(-1)$ & 11.600 & 10.332 & 1.268 \\
\hline 2 & $25(1)$ & $12(1)$ & $2(-1)$ & $3(1)$ & $2(-1)$ & $2(-1)$ & 9.133 & 9.657 & -0.524 \\
\hline 3 & $11(-1)$ & $12(1)$ & $6(1)$ & $1(-1)$ & $6(1)$ & $2(-1)$ & 8.550 & 8.157 & 0.393 \\
\hline 4 & $25(1)$ & $4(-1)$ & $6(1)$ & $3(1)$ & $2(-1)$ & $6(1)$ & 12.967 & 12.988 & -0.021 \\
\hline 5 & $25(1)$ & $12(1)$ & $2(-1)$ & $3(1)$ & $6(1)$ & $2(-1)$ & 10.383 & 9.859 & 0.524 \\
\hline 6 & $25(1)$ & $12(1)$ & $6(1)$ & $1(-1)$ & $6(1)$ & $6(1)$ & 11.467 & 11.657 & -0.19 \\
\hline 7 & $11(-1)$ & $12(1)$ & $6(1)$ & $3(1)$ & $2(-1)$ & $6(1)$ & 10.300 & 10.61 & -0.31 \\
\hline 8 & $11(-1)$ & $4(-1)$ & $6(1)$ & $3(1)$ & $6(1)$ & $2(-1)$ & 8.550 & 9.69 & -1.14 \\
\hline 9 & $11(-1)$ & $4(-1)$ & $2(-1)$ & $3(1)$ & $6(1)$ & $6(1)$ & 10.900 & 9.429 & 1.471 \\
\hline 10 & $25(1)$ & $4(-1)$ & $2(-1)$ & $1(-1)$ & $6(1)$ & $6(1)$ & 9.217 & 10.274 & -1.057 \\
\hline 11 & $11(-1)$ & $12(1)$ & $2(-1)$ & $1(-1)$ & $2(-1)$ & $6(1)$ & 7.800 & 7.693 & 0.107 \\
\hline 12 & $11(-1)$ & $4(-1)$ & $2(-1)$ & $1(-1)$ & $2(-1)$ & $2(-1)$ & 6.050 & 6.571 & -0.521 \\
\hline 13 & $18(0)$ & $8(0)$ & $4(0)$ & $2(0)$ & $4(0)$ & $4(0)$ & 3.550 & 3.783 & -0.233 \\
\hline 14 & $18(0)$ & $8(0)$ & $4(0)$ & $2(0)$ & $4(0)$ & $4(0)$ & 4.100 & 3.783 & 0.317 \\
\hline 15 & $18(0)$ & $8(0)$ & $4(0)$ & $2(0)$ & $4(0)$ & $4(0)$ & 3.700 & 3.783 & -0.083 \\
\hline
\end{tabular}

The protease production varied intherange of 3.550 (in run no. 13) to $12.967 \mathrm{U} / \mathrm{ml} / \mathrm{min}$ (run no. 4), this variation reflects the importance of medium optimization to attain higher productivity. Additionally, the low values of the residuals reflect the adequacy and accuracy of the design. The statistical analysis of Plackett-Burman design was performed (Table 2).

The analysis of variance (ANOVA) demonstrated that the model was highly significant as was evident from the Fisher's $F$-test with a very low probability value $(P$-value $)=0.001)$. The model $F$-value of 15.76 implies the model is significant. The higher $F$-value and the lower $P$-value, the more significant of the model. Models with $P$-values of less than 0.05 were considered to be significant. The $P$-value of the lack of fit error is another important parameter to evaluate the model, this $P$-value $(0.053)$ did not reach the level of significant. The lack of fit is an indication for the appropriateness of the data, as fitting of the model is required and reflects a good parameter. To check the goodness of fit of the model, the determination coefficient $\left(\mathrm{R}^{2}\right)$ was estimated The $\mathrm{R}^{2}$ values provide a measure of how much variability of the observed response can be explained by the experimental factors. The $\mathrm{R}^{2}$ value is always between 0 and 1 . The closer the $\mathrm{R}^{2}$ value to 1 , the stronger the model is, and the better it predicts the response. In our study, the value of $\mathrm{R}^{2}=94.03 \%$ indicated that $94.03 \%$ of the variability in the response could be explained by the model and only $5.97 \%$ of the total variations are not explained by the model, which may be back to the error. In addition, the value of the adjusted (adj.) $R^{2}$ is high enough to emphasize the accuracy of the relationships between the studied variables and protease production by the isolated fungus. 
Table 2Analysis of variance of the Plackett-Burman designf or the overall model as well as each variable affecting protease production by $M$. mucedo strain SEE1.

\begin{tabular}{|c|c|c|c|c|c|c|c|}
\hline Source & & Degree of freedom & $\begin{array}{l}\text { Contribution } \\
(\%)\end{array}$ & Adj Sum of squares & $F$-value & $P$-value & $\begin{array}{l}\text { Determination } \\
\text { coefficient }(\%)\end{array}$ \\
\hline \multirow{4}{*}{ Overall model } & Model & 7 & 94.03 & 117.72 & 15.76 & 0.001 & $\mathrm{R}^{2}=94.03$ \\
\hline & Lack of fit & 5 & 5.84 & 7.31 & 18.08 & 0.053 & Adj. $\mathrm{R}^{2}=88.07$ \\
\hline & Pure error & 2 & 0.13 & 0.16 & & & \\
\hline & Total error & 7 & 5.97 & 7.47 & & & \\
\hline \multirow{6}{*}{ Individual } & Glucose & 1 & 10.60 & 13.27 & 12.44 & 0.01 & \\
\hline & Peptone & 1 & 0.18 & 0.23 & 0.21 & 0.658 & \\
\hline & Casein & 1 & 6.59 & 8.25 & 7.74 & 0.027 & \\
\hline & $\mathrm{KH}_{2} \mathrm{PO}_{4}$ & 1 & 3.79 & 4.75 & 4.45 & 0.073 & \\
\hline & Olive cake & 1 & 0.10 & 0.12 & 0.12 & 0.744 & \\
\hline & CSL & 1 & 4.68 & 5.86 & 5.49 & 0.052 & \\
\hline
\end{tabular}

The significance of each of the tested variable was determined based on $P$ value. The statistical analysis of data obtained based on Plackett-Burman design show that, glucose with $P$-value of 0.01 was determined to be the most significant variable affecting protease production by $M$. mucedo strain SEE1 followed by casein with $P$-value of 0.027 , the lower probability values $(P \leq 0.05)$ of the factors indicates significant effect on protease production, the other variables of the medium components did not show any significance. The main effect of each variable on protease production was estimated (Figure 4), in which both of glucose and casein exerted significant positive effects in this respect. On the other hand, peptone exerted an insignificant negative effect. Although the other variables $\left(\mathrm{KH}_{2} \mathrm{PO}_{4}, \quad\right.$ olive cake and CSL $)$ showed positive effect, they were also out of significance. These findings are clearly presented in Pareto chart of the standardized effects (Figure 5), which allows detecting the order and significant effects of variables affecting protease production in Plackett-Burman design.

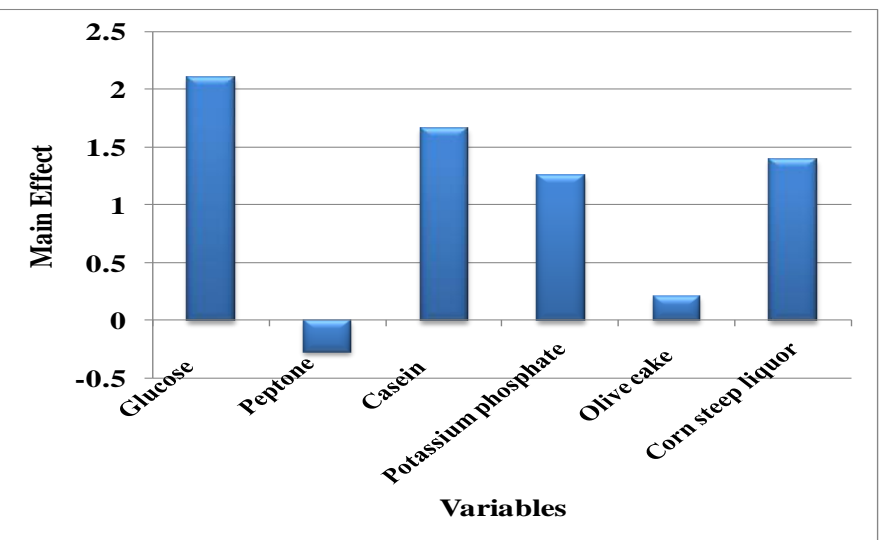

Figure4The main effects of the fermentation medium constituents on protease production by $M$. mucedo strain SEE1 according to the Packett-Burman experimental results.

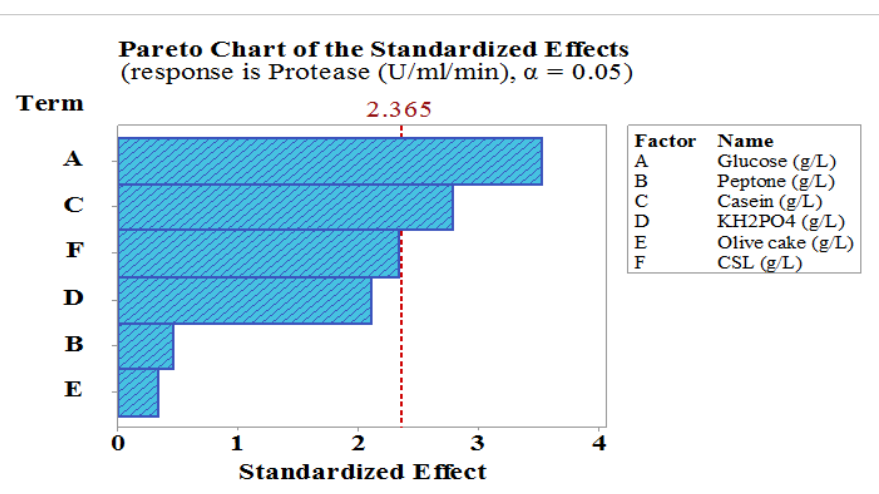

Figure 5 Pareto chart shows the order and significance of the variables affecting protease production by $M$. mucedo strain SEE1.
It demonstrates the relation between effects vs. ranks using the absolute values of the effects and draws a reference line on the chart (with a value of 2.365), which is calculated based on the data obtained from Packett-Burman experimental results. Any effect that extends past this reference line is potentially significant. As shown, glucose was the most significant variable affecting protease production at $99 \%$ confidence followed by casein at $97.30 \%$ confidence, while other variables are not significant. By neglecting the terms that were insignificant $(P>0.05)$, the first order polynomial prediction equation was derived, representing protease production as a function of the independent variables as follows:

$Y_{\text {(Protease activity) }}=2.80+0.1502 \mathrm{X}_{1}+0.415 \mathrm{X}_{3}$

The coefficients of glucose and casein of the previous equation were positive $(0.1502$ and 0.415 , respectively), which means that the increase in the concentrations of these variables could exert positive effect on protease activity. Glucose and casein were chosen for further optimization using central composite design (CCD), since these factors are the only significant positive variables on protease production. Both of them were tested around the high level and the other variables that exerted insignificant effect on protease production were maintained at the low levels in the next optimization step. Data of screening of the medium components with Plackett-Burman show that run no 4 was the highest, being $12.967 \mathrm{U} / \mathrm{ml} / \mathrm{min}$, which is higher by about 3.4 folds obtained before applying the Plackett-Burman design

\section{Central composite design for optimizing protease production}

Optimization was applied on the significant nutritional parameter selected from the preceding Plackett-Burman design, i.e glucose $\left(\mathrm{X}_{1}\right)$ and casein $\left(\mathrm{X}_{3}\right)$ using the central composite design (CCD) at five levels each. The other insignificant variables of the medium components were kept at their minimal concentrations. Central composite design matrix (coded and actual levels of the variables) and responses (experimental and predicted protease activity) for the 13 runs of the design are presented in Table 3.Theresponse by the fungus against the various runs of CCD shows considerable variation in protease activity. The highest levels of protease activity $(14.732 \mathrm{U} / \mathrm{ml} / \mathrm{min})$ were achieved in runs 4 and 6 ; while the lowest protease activity $(7.668 \mathrm{U} / \mathrm{ml} / \mathrm{min})$ was achieved in run number 9 , where $23.5 \mathrm{~g} / \mathrm{l}$ of glucose and $6 \mathrm{~g} / \mathrm{l}$ of casein were used.

The statistical analysis of the data (Table 4) shows that the value of $\mathrm{R}^{2}=$ $98.86 \%$ indicated that $98.86 \%$ of response variations was attributed to the independent variables and only $1.14 \%$ of the total variations cannot explained by the model. A regression model having an $\mathrm{R}^{2}$ value higher than 0.9 is considered as having a very high correlation (Chen et al., 2009). Therefore, the present $R^{2}$ value reflected a very good fit between the observed and predicted (calculated) protease responses, and implied that the model is reliable for protease production in the present study. In addition, the value of the adj. $\mathrm{R}^{2}(98.05 \%)$ was also very high to advocate for a high significance of the model. The predicted $\mathrm{R}^{2}$ value of $94.68 \%$ was in a reasonable agreement with the adj. $\mathrm{R}^{2}$ value. The high value of predicted $\mathrm{R}^{2}$ indicates how well the model predicts responses for new observations that are not tested in the design, this in turn; improve the predictive ability of the model. 
Table 3 Values of the independent variables used in central composite design matrix with response values of fungal protease production by $M$. mucedo strain SEE1.

\begin{tabular}{|c|c|c|c|c|c|c|c|}
\hline \multirow{2}{*}{ Run } & \multirow{2}{*}{$\begin{array}{l}\text { Codded value } \\
\text { Glucose }\left(\mathbf{X}_{1}\right) \\
\end{array}$} & \multirow[b]{2}{*}{ Casein $\left(\mathbf{X}_{3}\right)$} & \multicolumn{2}{|c|}{ Actual value (g/l) } & \multicolumn{2}{|c|}{ Protease activity $(\mathrm{U} / \mathrm{ml} / \mathrm{min})$} & \multirow{2}{*}{ Residuals } \\
\hline & & & Glucose & Casein & Experimental & Fitted & \\
\hline 1 & -1 & -1 & 20.00 & 4.00 & 10.277 & 10.04 & 0.237 \\
\hline 2 & 1 & -1 & 27.00 & 4.00 & 11.232 & 10.998 & 0.234 \\
\hline 3 & -1 & 1 & 20.00 & 8.00 & 8.050 & 8.293 & -0.243 \\
\hline 4 & 1 & 1 & 27.00 & 8.00 & 14.732 & 14.979 & -0.247 \\
\hline 5 & -1.414 & 0 & 18.55 & 6.00 & 9.323 & 9.321 & 0.002 \\
\hline 6 & 1.414 & 0 & 28.45 & 6.00 & 14.732 & 14.725 & 0.007 \\
\hline 7 & 0 & -1.414 & 23.50 & 3.17 & 9.005 & 9.34 & -0.335 \\
\hline 8 & 0 & 1.414 & 23.50 & 8.83 & 11.264 & 10.92 & 0.344 \\
\hline 9 & 0 & 0 & 23.50 & 6.00 & 7.668 & 8.05 & -0.382 \\
\hline 10 & 0 & 0 & 23.50 & 6.00 & 8.432 & 8.05 & 0.382 \\
\hline 11 & 0 & 0 & 23.50 & 6.00 & 8.050 & 8.05 & 0 \\
\hline 12 & 0 & 0 & 23.50 & 6.00 & 7.859 & 8.05 & -0.191 \\
\hline 13 & 0 & 0 & 23.50 & 6.00 & 8.241 & 8.05 & 0.191 \\
\hline
\end{tabular}

Table 4 Analysis of variance and regression coefficients for protease production by $M$. mucedo strain SEE1 using central composite design.

\begin{tabular}{llllll}
\hline Source & $\begin{array}{l}\text { Degree } \\
\text { freedom }\end{array}$ & $\begin{array}{l}\text { of } \\
\text { squares }\end{array}$ & $\begin{array}{l}\text { Adj } \text {-value } \\
\text { squm of }\end{array}$ & $\boldsymbol{P}$-value & $\begin{array}{l}\text { Regression } \\
\text { coefficient }\end{array}$ \\
\hline Model & 5 & 71.6782 & 121.37 & 0.000 & 8.05 \\
Linear & 2 & 31.7044 & 134.21 & 0.000 & 1.911 \\
$\mathrm{X}_{1}$ & 1 & 29.2096 & 247.3 & 0.000 & 0.558 \\
$\mathrm{X}_{3}$ & 1 & 2.4949 & 21.12 & 0.002 & 1.987 \\
Square & 2 & 31.7741 & 134.51 & 0.000 & 1.04 \\
$\mathrm{X}_{1} \mathrm{X}_{1}$ & 1 & 27.4552 & 232.45 & 0.000 & 1.432 \\
$\mathrm{X}_{3} \mathrm{X}_{3}$ & 1 & 7.5249 & 63.71 & 0.000 & \\
2 -Way Interaction & 1 & 8.1996 & 69.42 & 0.000 & \\
$\mathrm{X}_{1} \mathrm{X}_{3}$ & 1 & 8.1996 & 69.42 & 0.000 & \\
Error & 7 & 0.8268 & & & \\
Lack-of-Fit & 3 & 0.462 & 1.69 & & \\
Pure Error & 4 & 0.3648 & & & \\
Total & 12 & 72.505 & & &
\end{tabular}

The $P$-values were used as a tool to check the significance of each of the coefficients for the model as well as each tested factor, which, in turn, are necessary to understand the pattern of the mutual interactions between the test variables. Interpretation of the data was based on the signs (positive or negative effect on the response) and statistical significance of coefficients at $P \leq 0.05$ Interactions between two factors could appear as an antagonistic effect (negative coefficient) or a synergistic effect (positive coefficient). It can be seen from the degree of significance that the linear effects, quadratic effects and interaction between $\mathrm{X}_{1}$ (glucose) and $\mathrm{X}_{3}$ (casein) are significant, meaning that they can act as limiting factors for protease production, and little variation in their values will alter the protease production rate. However, the ANOVA of the regression mode demonstrates that the model is highly significant, as is evident from the very low $P$-value, which equals to zero.

\section{Model adequacy checking and validation}

Usually, it is necessary to check the fitted model to ensure that it provides an adequate approximation to the real system. Unless the model shows an adequate fit, proceeding with the investigation and optimization of the fitted response surface likely give poor or misleading results. Checking of the adequacy of the model needs all of the information on the lack of fit, which is contained in the residuals. Plotting these residuals against the fitted values of protease production (Figure 6) shows equal scatter of the residual data above and below the $\mathrm{X}$-axis indicating that the variance was independent of protease production, thus supporting the adequacy of the model fit.

In order to evaluate the relationship between dependent and independent variables and to determine the optimum levels of glucose and casein corresponding to the maximum protease production, a second-order polynomia model was proposed. The second-order polynomial equation that defines predicted protease response $(Y)$ was obtained to be:

$Y_{\text {(Protease activity) }}=8.05+1.911 \mathrm{X}_{1}+0.558 \mathrm{X}_{3}+1.987 \mathrm{X}_{1}^{2}+1.04 \mathrm{X}_{3}^{2}+1.432 \mathrm{X}_{1} \mathrm{X}_{3}$

To visualize the previous relationship between protease response and the interactions among the tested variables, graphical three-dimensional and Contour plots were generated (Figure 7) in order to determine the optimum conditions for protease production at the different levels of both glucose and casein. Exploring both figures reveal that the maximum protease production appeared at high levels of both $\mathrm{X}_{1}$ and $\mathrm{X}_{3}$ and low concentrations of both variables supported low protease production.

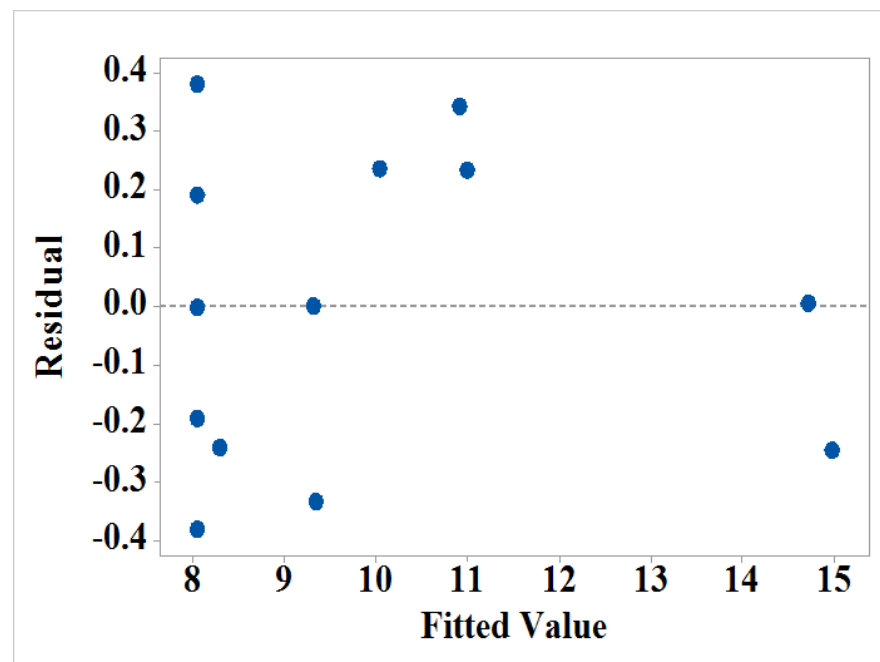

Figure 6 Plot of residuals against fitted values for protease production by $M$ mucedo strain SEE1. 

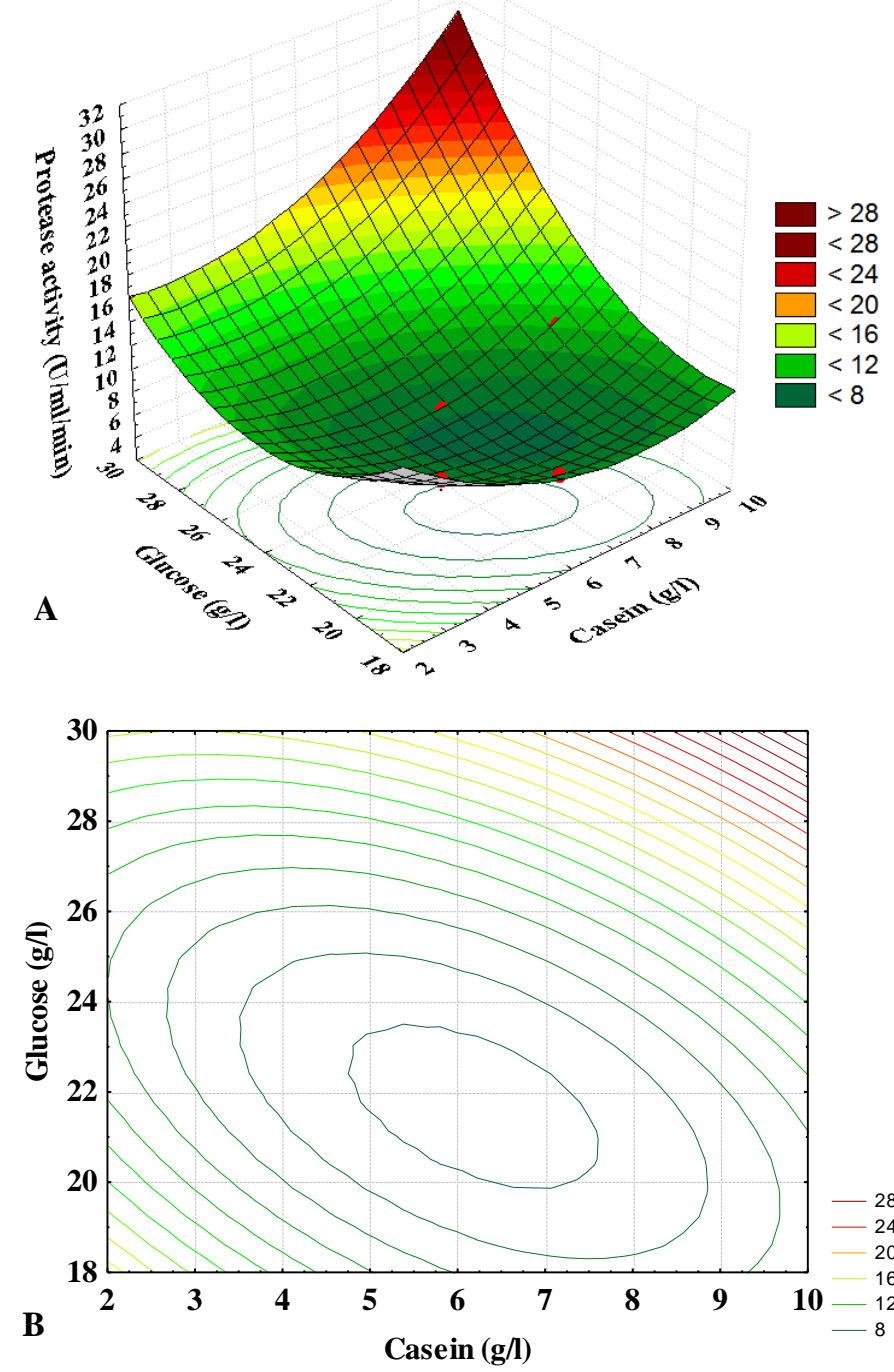

Figure 7 A) Three-dimensional response surface and B) Contour plot showing the interactive effects of independent variables (glucose and casein) on protease production by M. mucedo strain SEE1.

The previous model was experimentally validated, in order to determine the prediction accuracy of the model and to verify the optimization results, experiments were repeated in triplicates under optimized culture conditions obtained from fitted protease production model. Under these conditions, $14.90 \pm$ $0.31 \mathrm{U} / \mathrm{ml} / \mathrm{min}$ of protease was obtained. This value of protease activity corresponds very well to the values predicted by the fitted model 14.850 $\mathrm{U} / \mathrm{ml} / \mathrm{min}$. Comparing protease production after CCD optimization, reveals 3.82 and 1.14-fold increment compared with before and after Plackett-Burman results, respectively.

Both glucose and casein proved to be the most potent nutritional factors affecting protease production. Glucose is simple carbon source, which is required, nearly in all growth stages of microorganism, the small amount encourage the growth of the fungus at the initial growth stage, so it could be considered as a limiting nutritional factor for both the microbial growth and protease production (Rao $\boldsymbol{e}$ al., 2009; Abou-Ayana et al., 2015). However, other reports observed that the complex carbon source constitute better substrates for protease production than simple sugars such as glucose, which induced catabolic repression especially at the high concentrations (Reddy $\boldsymbol{e t}$ al., 2008). Glucose and casein were found to be the best carbon and nitrogen sources for protease production by Mucor mucedo DSM 809 (Yegin et al., 2010). The presence of the substrate (casein) can induce protease secretion, however; high levels of the end products as an action of proteases, such as amino acids, $\mathrm{NH}^{4+}$, and easily metabolizable sources of carbon may repress enzyme production (Souza et al., 2015), therefore, protease productivity could be affected by the nature of carbon and nitrogen sources (Vijayaraghavan et al., 2012). Finally, extracellular protease enzyme may be secreted constitutively at low levels regardless of the availability of a substrate (Geisseler and Horwath, 2008).

\section{Production of amino acids on the optimized fermentation medium}

Nowadays, the increasing need to replace chemically synthesized compounds by environmental friendly ones using biological processes is driving the research for microbial factories. The industrial production of amino acids includes several examples of success stories using microorganisms to convert inexpensive substrates into valuable products. Herein, M. mucedo strain SEE1 was growing on optimized batch fermentation medium and the associated amino acids had been investigated. Obtained results indicated that 16 amino acids have been determined individually (Table 5).

Table 5 Amino acids profile produced by $M$. mucedo strain SEE1 on the optimized fermentation medium.

\begin{tabular}{lc}
\hline Amino acid & Amount $(\boldsymbol{\mu} \mathbf{g} / \mathbf{m l}) \pm$ standard error \\
\hline Alanine & $138.7 \pm 2.3$ \\
Arginine & $580 \pm 0.6$ \\
Aspartic acid & $460.1 \pm 2.9$ \\
Cysteine & $36.0 \pm 0.5$ \\
Glutamic acid & $391.0 \pm 1.7$ \\
Glycine & $196.6 \pm 1.2$ \\
Histidine & $1155.3 \pm 2.8$ \\
Isoleucine & $580.0 \pm 1.9$ \\
Leucine & $386.5 \pm 0.9$ \\
Lysine & $897.4 \pm 3.3$ \\
Phenylalanine & $299.0 \pm 0.7$ \\
Proline & $114.0 \pm 0.3$ \\
Serine & $570.8 \pm 1.0$ \\
Threonine & $325.3 \pm 3.0$ \\
Tyrosine & $634.0 \pm 2.6$ \\
Valine & $490.8 \pm 1.4$ \\
\hline
\end{tabular}

The content of histidine followed by lysine, tyrosine, arginine and isoleucine were significantly superior amino acids. However, alanine, cysteine, proline, glycine and phenylalanine showed less significant superiority, where, these amino acids are essential for growth of organisms, whereas, histidine, lysine, isoleucine and serine are non-essential. Contrarily, the amino acids, alanine and glycine were reported to be secreted byLactobacillus salivarius (Lee et al., 2014). Similar studies showed that the amino acids, $L$-phenylalanine, $L$-threonine and L-cysteine have been obtained by E. coli strains (Ikeda, 2003), and Lglutamine wasproduced by Corynebacterium glutamicum, (Kuethe et al., 2007). Other amino acids produced by Corynebacteria include L-valine, L-isoleucine, L-threonine, L-aspartic acid and L-alanine (Eggeling and Sahm, 2011; Schneider et al., 2013).

Generally, microorganisms produce the 20 kinds of amino acids only in the amounts they need. They have a mechanism for regulating the quantities and qualities of enzymes to yield amino acids only in the amounts necessary for themselves (Ivanov et al., 2013). Herein, M. mисеdo strain SEE1 was directed, during the preceding optimization study, to accumulate several amino acids (up to 16) in its growth medium, encouraging the industrial production of such amino acids using this fungus and the proposed fermentation condition described earlier.

\section{CONCLUSION}

The fungus Mucor sp. was isolated according to its proteolytic activity on skim milk agar. Identification basis depend upon microscopic, morphological as well as $18 \mathrm{~S}$ rRNA sequence confirmed this isolate namely, $M$. mucedo strain SEE1 under the accession number KP736529.Following the optimization procedure of protease, i.e. Plackett-Burman and central composite design, both glucose and casein have significant effect on the protease production. Amino acids produced $(\mu \mathrm{g} / \mathrm{ml})$ in the fermentation medium revealed in 16 amino acids. Histidine came in the first order (1155.3), followed by lysine (897.4), tyrosine (634), argentine (580) and isoleucine (580). Other amino acids e.g. alanine, cysteine and proline were measured in little amount. Ultimately, the fungus $M$. mucedo strain SEE1 can be exploited to produce some of amino acids in large scale, in which amino acids play important roles in the life, e.g. as animal feed additives, flavor enhancer, pharmaceuticals, cosmetics and production of lactic acid and some antibiotics.

\section{CONFLICT OF INTERESTS}

The author declares that there is no conflict of interests.

\section{REFERENCES}

AKHNAZAROVA, S. AND AFAROV, K. V., Experiment Optimization in Chemistry and Chemical Engineering, 1982. Mir, Moscow.

ALEKSIEVA, P. AND PEEVA, L. 2000. Investigation of acid proteinase biosynthesis by the fungus Humicola lutea 120-5 in an airlift bioreactor. Enzyme and microbial technology, 26, 402-405. 
ALTSCHUL, S. F., MADDEN, T. L., SCHÄFFER, A. A., ZHANG, J., ZHANG, Z., MILLER, W. AND LIPMAN, D. J. 1997. Gapped BLAST and PSI-BLAST: a new generation of protein database search programs. Nucleic acids research, 25, 3389-3402.

ANDRADE, V. S., SARUBBO, L. A., FUKUSHIMA, K., MIYAJI, M. NISHIMURA, K. AND CAMPOS-TAKAKI, G. M. D. 2002. Production of extracellular proteases by Mucor circinelloides using D-glucose as carbon source/substrate. Brazilian Journal of Microbiology, 33, 106-110.

ANITHA, T. AND PALANIVELU, P. 2013. Purification and characterization of an extracellular keratinolytic protease from a new isolate of Aspergillus parasiticus. Protein expression and purification, 88, 214-220.

ANITHA, T. AND PALANIVELU, P. 2013. Purification and characterization of an extracellular keratinolytic protease from a new isolate of Aspergillus parasiticus. Protein expression and purification, 88, 214-220.

AYANA, I. A. A., IBRAHIM, A. E. AND SABER, W. I. 2015. Statistical optimization of milk clotting enzyme biosynthesis by Mucor mucedo KP736529 and its further application in cheese production. International Journal of Dairy Science, 10, 61-76.

CHEN, X.-C., BAI, J.-X., CAO, J.-M., LI, Z.-J., XIONG, J., ZHANG, L., HONG, Y. AND YING, H.-J. 2009. Medium optimization for the production of cyclic adenosine 3', 5'-monophosphate by Microbacterium sp. no. 205 using response surface methodology. Bioresource technology, 100, 919-924.

DEMAIN, A. L. 2000. Microbial biotechnology. Trends in biotechnology, 18, 26-31

DOMSCH, K. H., GAMS, W. AND ANDERSON, T.-H. 1980. Compendium of soil fungi, Soc General Microbiol.

DUTTA, J. R., DUTTA, P. K. AND BANERJEE, R. 2004. Optimization of culture parameters for extracellular protease production from a newly isolated Pseudomonas sp. using response surface and artificial neural network models. Process Biochemistry, 39, 2193-2198.

GARG, R. P., QIAN, X. L., ALEMANY, L. B., MORAN, S. AND PARRY, R. J. 2008. Investigations of valanimycin biosynthesis: elucidation of the role of seryltRNA. Proceedings of the National Academy of Sciences, 105, 6543-6547.

GEISSELER, D. AND HORWATH, W. R. 2008. Regulation of extracellular protease activity in soil in response to different sources and concentrations of nitrogen and carbon. Soil Biology and Biochemistry, 40, 3040-3048.

GESSESSE, A. 1997. The use of nug meal as a low-cost substrate for the production of alkaline protease by the alkaliphilic Bacillus sp. AR-009 and some properties of the enzyme. Bioresource technology, 62, 59-61.

GUPTA, R., BEG, Q. AND LORENZ, P. 2002. Bacterial alkaline proteases: molecular approaches and industrial applications. Applied microbiology and biotechnology, 59, 15-32.

HAKI, G. AND RAKSHIT, S. 2003. Developments in industrially importan thermostable enzymes: a review. Bioresource technology, 89, 17-34.

IKEDA, M. 2003. Amino acid production processes. Microbial production of $l$ amino acids. Springer.

IKRAM-UL-HAQ AND MUKHTAR, H. 2007. Biosynthesis of acid proteases by penicillium griseoroseum ih-02 in solid-state fermentation.Pakistan journal of botany, 39, 2717-2724.

IVANOV, K., STOIMENOVA, A., OBRESHKOVA, D. AND SASO, L. 2013 Biotechnology in the Production of Pharmaceutical Industry Ingredients: Amino Acids. Biotechnology \& Biotechnological Equipment, 27, 3620-3626.

JOO, H. S., KUMAR, C., PARK, G. C., PAIK, S. AND CHANG, C. S. 2003. Oxidant and SDS-stable alkaline protease from Bacillus clausii I-52: Production and some properties. Journal of applied microbiology, 95, 267-272.

KEMBHAVI, A. A., KULKARNI, A. AND PANT, A. 1993. Salt-tolerant and thermostable alkaline protease from Bacillus subtilis NCIM No. 64. Applied biochemistry and biotechnology, 38, 83-92.

KRANTHI, V., MURALIDHAR, R. AND JAGANMOHAN, P. 2012 Production of protease by Aspergillus flavus through solid state fermentation using different oil seed cakes. International Journal of Microbiological Research, 3, 12-15.

KUETHE, J. T., GAUTHIER, D. R., BEUTNER, G. L. AND YASUDA, N. 2007. A Concise Synthesis of (S)-N-Ethoxycarbonyl- $\alpha$-methylvaline. The Journal of organic chemistry, 72, 7469-7472.

KUMAR, S., SHARMA, N. S., SAHARAN, M. R. AND SINGH, R. 2005. Extracellular acid protease from Rhizopus oryzae: purification and characterization. Process Biochemistry, 40, 1701-1705.

LEE, K., KIM, H.-J. AND PARK, S.-K. 2014. Amino acids analysis during lactic acid fermentation by single strain cultures of lactobacilli and mixed culture starter made from them. African Journal of Biotechnology, 13, 2867-2873.

MACCHIONE, M. M., MERHEB, C. W., GOMES, E. AND DA SILVA, R. 2008. Protease production by different thermophilic fungi. Applied biochemistry and biotechnology, 146, 223-230.

MERHEB, C. W., CABRAL, H., GOMES, E. AND DA-SILVA, R. 2007. Partial characterization of protease from a thermophilic fungus, Thermoascus aurantiacus, and its hydrolytic activity on bovine casein. Food chemistry, 104, 127-131.

MERHEB-DINI, C., GOMES, E., BOSCOLO, M. AND DA SILVA, R. 2010 Production and characterization of a milk-clotting protease in the crude enzymatic extract from the newly isolated Thermomucor indicae-seudaticae N31. Food Chemistry, 120, 87-93.

MOO-YOUNG, M. 2011. Comprehensive biotechnology, Newnes.

O’DONNELL, D., WANG, L., XU, J., RIDGWAY, D., GU, T. AND MOOYOUNG, M. 2001. Enhanced heterologous protein production in Aspergillus niger through $\mathrm{pH}$ control of extracellular protease activity. Biochemical Engineering Journal, 8, 187-193.

REDDY, L., WEE, Y.-J., YUN, J.-S. AND RYU, H.-W. 2008. Optimization of alkaline protease production by batch culture of Bacillus sp. RKY3 through Plackett-Burman and response surface methodological approaches. Bioresource Technology, 99, 2242-2249.

SABOTIČ, J. AND KOS, J. 2012. Microbial and fungal protease inhibitorscurrent and potential applications. Applied microbiology and biotechnology, 93, 1351-1375.

SAITOU, N. AND NEI, M. 1987. The neighbor-joining method: a new method for reconstructing phylogenetic trees. Molecular biology and evolution, 4, 406425.

SARAN, S., ISAR, J. AND SAXENA, R. K. 2007. A modified method for the detection of microbial proteases on agar plates using tannic acid. Journal of biochemical and biophysical methods, 70, 697-699.

SCHNEIDER, J., NIERMANN, K. AND WENDISCH, V. F. 2011. Production of the amino acids L-glutamate, L-lysine, L-ornithine and L-arginine from arabinose by recombinant Corynebacterium glutamicum. Journal of biotechnology, 154, 191-198.

SINGH, J., VOHRA, R. AND SAHOO, D. K. 2004. Enhanced production of alkaline proteases by Bacillus sphaericus using fed-batch culture. Process Biochemistry, 39, 1093-1101.

SOUZA, P. M. D., BITTENCOURT, M. L. D. A., CAPRARA, C. C., FREITAS, M. D., ALMEIDA, R. P. C. D., SILVEIRA, D., FONSECA, Y. M., FERREIRA FILHO, E. X., PESSOA JUNIOR, A. AND MAGALHÃES, P. O. 2015. A biotechnology perspective of fungal proteases. Brazilian Journal of Microbiology, 46, 337-346.

RAO,S. C., SATHISH, T., PENDYALA, B., KUMAR, T. P. AND PRAKASHAM, R. S. 2009. Development of a mathematical model for Bacillus circulans growth and alkaline protease production kinetics. Journal of Chemical Technology and Biotechnology, 84, 302-307.

SUGANTHI, C., MAGESWARI, A., KARTHIKEYAN, S., ANBALAGAN, M., SIVAKUMAR, A. AND GOTHANDAM, K. 2013. Screening and optimization of protease production from a halotolerant Bacillus licheniformis isolated from saltern sediments. Journal of Genetic Engineering and Biotechnology, 11, 47-52. TAMURA, K., DUDLEY, J., NEI, M. AND KUMAR, S. 2007. MEGA4: molecular evolutionary genetics analysis (MEGA) software version 4.0. Molecular biology and evolution, 24, 1596-1599.

TANG, L., ZHANG, Y.-X. AND HUTCHINSON, C. R. 1994. Amino acid catabolism and antibiotic synthesis: valine is a source of precursors for macrolide biosynthesis in Streptomyces ambofaciens and Streptomyces fradiae. Journal of bacteriology, 176, 6107-6119.

VENTURA, A. K., SAN GABRIEL, A., HIROTA, M. AND MENNELLA, J. A. 2012. Free amino acid content in infant formulas. Nutrition \& Food Science, 42, 271-278.

VIJAYARAGHAVAN, P., VIJAYAN, A., ARUN, A., JENISHA, J. AND VINCENT, S. G. P. 2012. Cow dung: a potential biomass substrate for the production of detergent-stable dehairing protease by alkaliphilic Bacillus subtilis strain VV

VISHWANATHA, K., RAO, A. A. AND SINGH, S. A. 2010. Acid protease production by solid-state fermentation using Aspergillus oryzae MTCC 5341: optimization of process parameters. Journal of industrial microbiology \& biotechnology, 37, 129-138.

VISHWANATHA, K. S., RAO, A. A. AND SINGH, S. A. 2010. Production and characterization of a milk-clotting enzyme from Aspergillus oryzae MTCC 5341 Applied microbiology and biotechnology, 85, 1849-1859.

YEGIN, S. AND FERNÁNDEZ-LAHORE, M. 2013. Production of extracellular aspartic protease in submerged fermentation with Mucor mucedo DSM 809. African Journal of Biotechnology, 9, 6380-6386.

ZAMBARE, V., NILEGAONKAR, S. AND KANEKAR, P. 2011. A novel extracellular protease from Pseudomonas aeruginosa MCM B-327: enzyme production and its partial characterization. New biotechnology, 28, 173-181. 